\title{
Micropalaeontological evidence of brackish water conditions during deposition of the Knorringfjellet Formation, Late Triassic-Early Jurassic, Spitsbergen
}

\author{
Jenö Nagy ${ }^{1}$ \& Sigrid H. Berge ${ }^{2}$ \\ 1 Department of Geosciences, University of Oslo, PO Box 1047 Blindern, NO-0316 Oslo, Norway \\ 2 Geoservices, Jakob Askelandsvei 21, P.O. Box 1058 Lura, NO-4391 Sandnes, Norway
}

\section{Keywords}

Foraminiferal facies; hyposaline; hypoxic tendency; low diversity; marine shelf;

stratigraphy.

\section{Correspondence}

Jenö Nagy, Department of Geosciences, University of Oslo, P.O. Box 1047 Blindern, NO-0316 Oslo, Norway. E-mail:

jeno.nagy@geo.uio.no

doi:10.1111/j.1751-8369.2007.00038.x

\begin{abstract}
The Knorringfjellet Formation is a succession of mudstones and sandstones, ranging in age from Norian to Toarcian in western and west-central Spitsbergen, and contains several unconformities with associated hiatuses. Its foraminiferal succession consists almost exclusively of agglutinated taxa, shows extremely low assemblage diversities and a dominance of small-sized species. These faunal features signalize restricted environmental conditions (in contrast to those of a normal marine shelf). Comparisons with ancient and modern analogues suggest that the main restricting factor was hyposaline conditions, to a lesser extent augmented by hypoxia in near-bottom waters. These conditions were caused by high fluvial influx creating gravity stratified water masses. The depositional area was part of an extensive but shallow shelf embayment, which had an open connection to the north to the polar ocean basin. Discontinuities recognized in the foraminiferal succession indicate depositional unconformities within the formation.
\end{abstract}

This study deals with the depositional conditions of the Late Triassic-Middle Jurassic Knorringfjellet Formation, a shallow marine succession of interbedded mudstones and sandstones widely exposed in Spitsbergen. The formation is partly condensed, and includes several shorter and longer depositional breaks. The time-equivalent sediment package of the Barents Sea shelf is a much thicker and more continuous succession, and includes important potential petroleum reservoirs.

The foraminiferal assemblages of the Knorringfjellet Formation are almost entirely agglutinated and have extremely low diversities, suggesting restricted environments (i.e., conditions diverging from those of a normal marine shelf). The purpose of this study is to elucidate the restricting environmental factors by means of foraminiferal facies parameters, supplemented by comparisons with modern and ancient analogues. This paper presents the first detailed foraminiferal analysis of the Knorringfjellet Formation. Owing to the pioneering nature of the research, several of the observed species are apparently new and await formal description, hence the common use of open nomenclature in the species determinations.
The study is mainly based on a section sampled in the Festningen profile, located in western Spitsbergen, where the foraminiferal assemblages of the Knorringfjellet Formation have been quantitatively analysed (Fig. 1). Data from a similarly analysed section located at Marhøgda in central Spitsbergen are also included. In addition, reconnaissance foraminiferal studies have been carried out at the Juvdalen and Drønbreen sections, in central Spitsbergen.

\section{Stratigraphic setting}

The Knorringfjellet Formation comprises the upper part of the Kapp Toscana Group (Fig. 2), which is a prominent sedimentary package widely exposed in western, central and eastern Spitsbergen, on the eastern islands of the Svalbard Archipelago, and has also been penetrated by numerous exploratory petroleum wells on the southwestern Barents Sea shelf. The dominant lithologies of the group are shales, mudstones and sandstones. The age of the group ranges from Carnian to Toarcian in western and west-central Spiesbergen, where its aggregate 


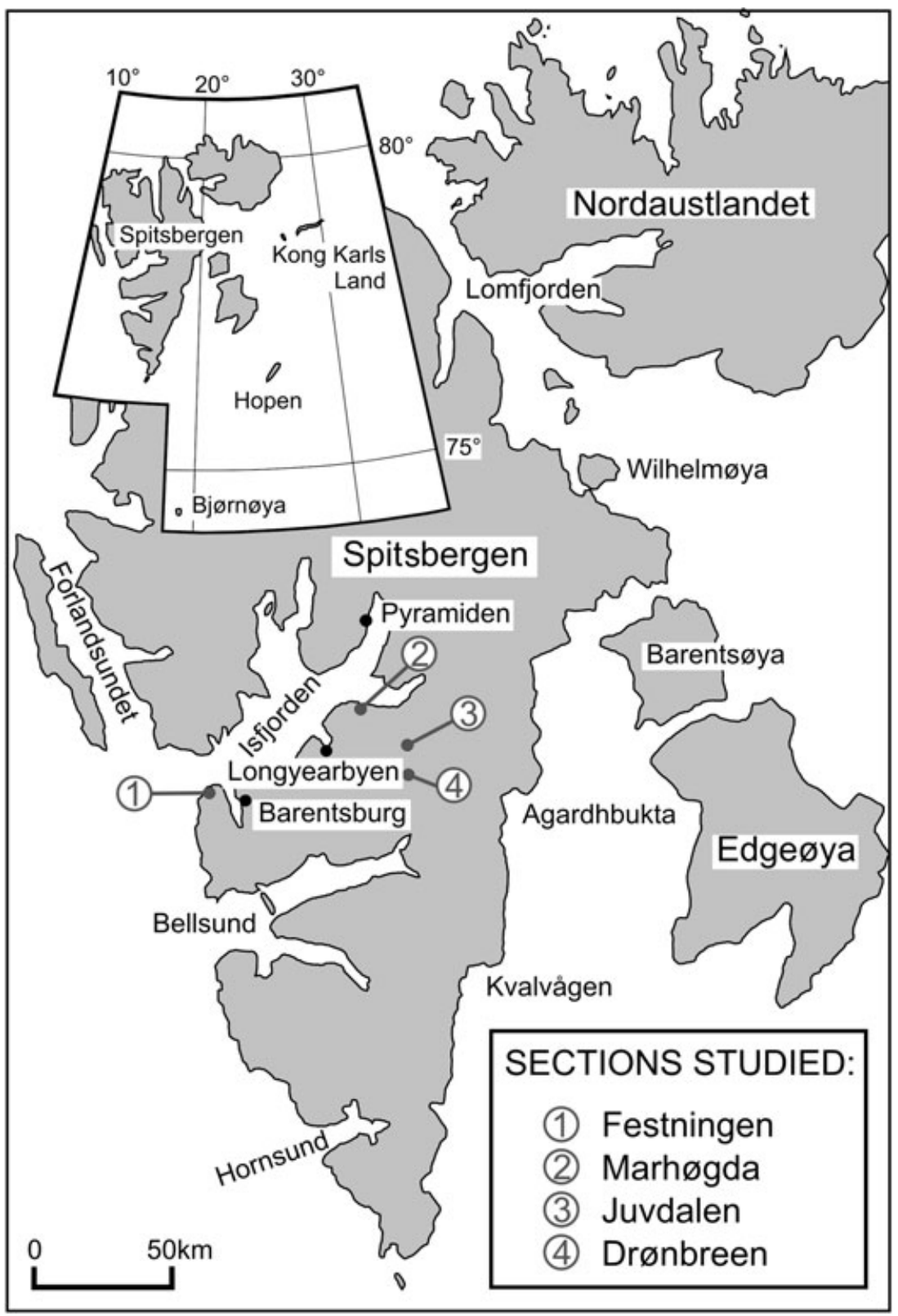

Fig. 1 Location map showing positions of the studied sections in western and central Spitsbergen. thickness reaches ca. $360 \mathrm{~m}$, and from Ladinian to Bajocian on the Barents Sea shelf, where it attains an aggregate thickness of $2000 \mathrm{~m}$. Deposition took place generally in an open shallow shelf, nearshore to deltaic environments characterized by shallow marine and coastal reworking of sediments (Mørk et al. 1982). The stratigraphy of the group was emended by Mørk et al. (1999).

In Svalbard, the Kapp Toscana Group begins with the Early Carnian Tschermakfjellet Formation, which is a shale-dominated open shelf to prodelta succession (Fig. 2). This grades normally upwards to the De Geerdalen Formation, which is dominated by numerous parasequences coarsening upwards from shale to sandstone. The De Geerdalen Formation was deposited in prodelta, delta front and delta plain environments from Early Carnian to Early Norian times.

The De Geerdalen Formation is overlain by the Knorringfjellet Formation with a basal unconformity. This break is usually marked by a transgressive polymict conglomerate with phosphatic nodules forming the base of the sand-dominated Slottet Bed. The top of the Knorringfjellet Formation is also defined by an unconformity and associated hiatus. This is in turn overlain by the Brentskardhaugen Bed, another polymict conglomerate 
Fig. 2 Stratigraphical scheme of the Kapp Toscana Group across Spitsbergen from west to east.

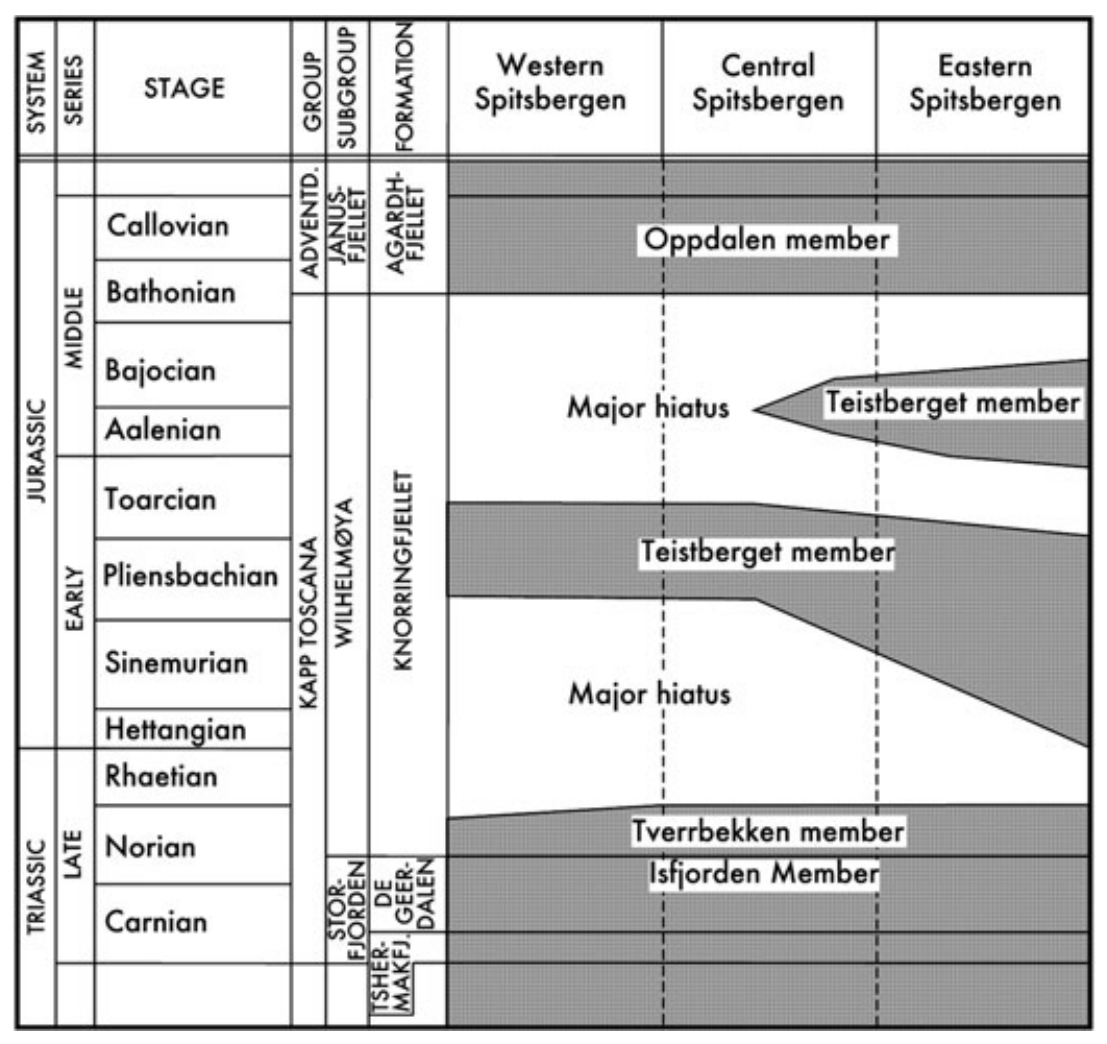

typified by phosphatic clasts, which forms the transgressive base of the overlying Agardhfjellet Formation.

The Knorringfjellet Formation ranges in age from Norian to probably Toarcian in western and west-central Spitsbergen, whereas in eastern Spitsbergen and on Kong Karls Land its time span is from Norinan to Bathonian (Pčelina 1965; Bjærke \& Dypvik 1977; Korčinskaja 1980; Bäckström \& Nagy 1985). The fossil groups used for dating are usually palynomorphs and bivalves; ammonites are seldom used.

The Knorringfjellet Formation is subdivided into two informal members that both consist of mudstones and sandstones interbedded in varying proportions (Fig. 2). The subdivision is based on the presence of a major unconformity separating the two members (Korčinskaja 1980; Pčelina 1980; Mørk et al. 1999). The lower Tverrbekken member constitutes the Late Triassic interval of the formation, whereas the overlying Teistberget member comprises its Early Jurassic part. In western and west-central areas the most extensive intervening hiatus is believed to represent the Late Norian-Early Pliesbachian time span.

The Knorringfjellet Formation together with timeequivalent formations elsewhere in Svalbard compose the Wilhelmøya Subgroup. Stratigraphically, this is a complex succession (particularly when viewed regionally) because of the condensed intervals, hiatuses and the scarcity of age-diagnostic fossils. In western, central and eastern Spitsbergen the Knorringfjellet Formation makes up the whole Wilhelmøya Subgroup. In the SørkappHornsund area the Smalegga Formation of sandstones with phosphatic pebbles is regarded as time equivalent to the Knorringfjellet Formation (Pčelina 1980; Mørk et al. 1999). In eastern Svalbard the time span of the Knorringfjellet Formation comprises a succession that includes the Flatsalen, Svenskøya and Kongsøya formations. This eastern succession represents a transition to the Early Norian-Bathonian Realgrunnen Subgroup of the southwestern Barents Sea shelf. The Realgrunnen Subgroup is of shallow shelf, marginal marine and deltaic origin, but is much more complete than its northern and north-eastern counterparts.

\section{Material and methods}

The samples analysed for foraminifera were taken from mudstone intervals dominating the Knorringfjellet Formation. These sediments have been strongly affected by diagenetic processes, and their high degree of lithification required intensive laboratory processing to obtain an adequate degree of disintegration. A commercially produced tenside diluted with methanol has been used as a disintegrating compound, in accordance with a procedure 
described by Nagy (2005). After disintegration the samples were sieved in the usual way. For the foraminiferal analysis the size fractions of 90-125, 125-500 and $>500 \mu \mathrm{m}$ have been used.

The faunal abundance is calculated as the number of individuals per gram of dry sediment. The assemblage diversities are portrayed by the information function $H(S)$ and the Fisher alpha index. The calculation of these parameters has been recently reviewed by Murray (2006). The dominance in a given sample is expressed as the percentage of the most common species. The degree of assemblage similarities between adjacent samples in a stratigraphic series is measured by means of the similarity index, described by Sanders (1960). The foraminiferal preparations forming the basis of this study will be deposited with the palaeontological material of the Natural History Museum of the University of Oslo.

\section{Sedimentary stratigraphic and biofacies record}

\section{Tverrbekken member of the Festningen section}

In this section the Knorringfjellet Formation is $22.8 \mathrm{~m}$ thick, and the Tverrbekken member accounts for the lower $11.8 \mathrm{~m}$ of the formation (Fig. 3). The lower $3 \mathrm{~m}$ of the member is made up of the Slottet Bed, the basal $20 \mathrm{~cm}$ of which is the transgressive polymict conglomerate mentioned above. The clast content of the conglomerate is dominated by phosphatic nodules, but in addition pebbles of quartzite and rock fragments are also present. The sandstone that forms the main body of the Slottet Bed is medium grained and heavily bioturbated. It contains small phosphatic pebbles, coalified plant fragments and some shell pieces. Thin sections of the basal conglomerate reveal foraminiferal tests, in accordance with its marine transgressive nature.

The middle and upper parts of the Tverrbekken member (above the Slottet Bed) contain six distinct sandstone beds separated by thicker mudstone intervals. The sandstones are densely cemented and heavily bioturbated, as is also revealed by thin sections. Owing to the intensive biogenic mixing primary sedimentary structures appear to have been destroyed, with a few exceptions.

The mudstones are generally dark-grey to grey, with total organic carbon (TOC) content ranging from 0.9 to $1.6 \%$ (Fig. 4). The presence of diffuse lamination suggests only a low degree of bioturbation. The calcium carbonate content of the mudstones ranges from 0.02 to $2.00 \%$. Red weathering siderite cement is typical for the sandstones, whereas lenticular siderite concretions in the mudstones are commonly concentrated in discrete horizons.

The foraminiferal assemblages in the member are almost entirely agglutinated. There was just a single sample (no. 1) that contained a few calcareous tests belonging to Eoguttulina liassica (Strickland 1846). The quantitatively dominant species are Ammodiscus aff. yonsnabensis Nagy, Løfaldli \& Bomstad 1983, Trochammina aff. eoparva Nagy \& Johansen 1991 and Bulbobaculites aff. vermiculus Nagy \& Seidenkrantz 2003 (Fig. 5). The species diversity is low, as is also shown by $H(S)$ values ranging from 0.7 to 1.4. The species dominance is correspondingly high (Fig. 6). The assemblages are strongly dominated by small-sized taxa.

The upper boundary of the Tverrbekken member is formed by the top surface of its upper sandstone bed, at $11.8 \mathrm{~m}$ in the section. This surface is heavily bioturbated and partly siderite cemented, thus revealing features of an unconformity including a major hiatus. Typical trace fossils in the sandstone immediately below this horizon include Thalassinoides, Rhizocorallium, Phoebichnus trochoides, Chondrites and Planolites. The first two of these traces are typical for the Glossifungites ichnofacies (in the sense of Pemberton \& MacEachern [1992]), which are commonly associated with bed surfaces cut by unconformities.

\section{Teistberget member of the Festningen section}

The total thickness of the Teistberget member is $11.0 \mathrm{~m}$. Its lower and middle parts consist generally of mudstones, whereas the upper part is dominated by sandstones (Fig. 3). The thinner sandstone beds are siderite cemented and strongly bioturbated. Scattered siderite concretions occur in the mudstones.

The Teistberget mudstones are clearly different from those of the underlying Tverrbekken member by being lighter in colour, softer, more silty and weathered to pieces of more blocky appearance. Their TOC content is lower, ranging from 0.2 to $1.0 \%$ (Fig. 4). The calcium carbonate content of the mudstones is extremely low, except in the sample taken at the base of the member where $33 \%$ is measured. This relatively high value is associated with the immediately underlying unconformity surface. Above this level and to the top of the member, the carbonate values range from 0.03 to $1.68 \%$.

The foraminiferal assemblages of this member are almost exclusively agglutinated, similar to the underlying strata (Fig. 5). Calcareous forms were again observed only in a single sample (no. 15), where this group is represented by a few specimens of Astacolus sp. The foraminiferal succession is heavily dominated by the smallsized species $A$. aff. yonsnabensis, which forms virtually monospecific assemblages in the upper part of the member. A relatively common small-sized form is $T$. aff. eoparva, which exceeds $10 \%$ in three samples. The other species show a more scattered distribution, with 
Fig. 3 Lithostratigraphic column of the Knorringfjellet Formation at Festningen, including the position of the analysed samples.

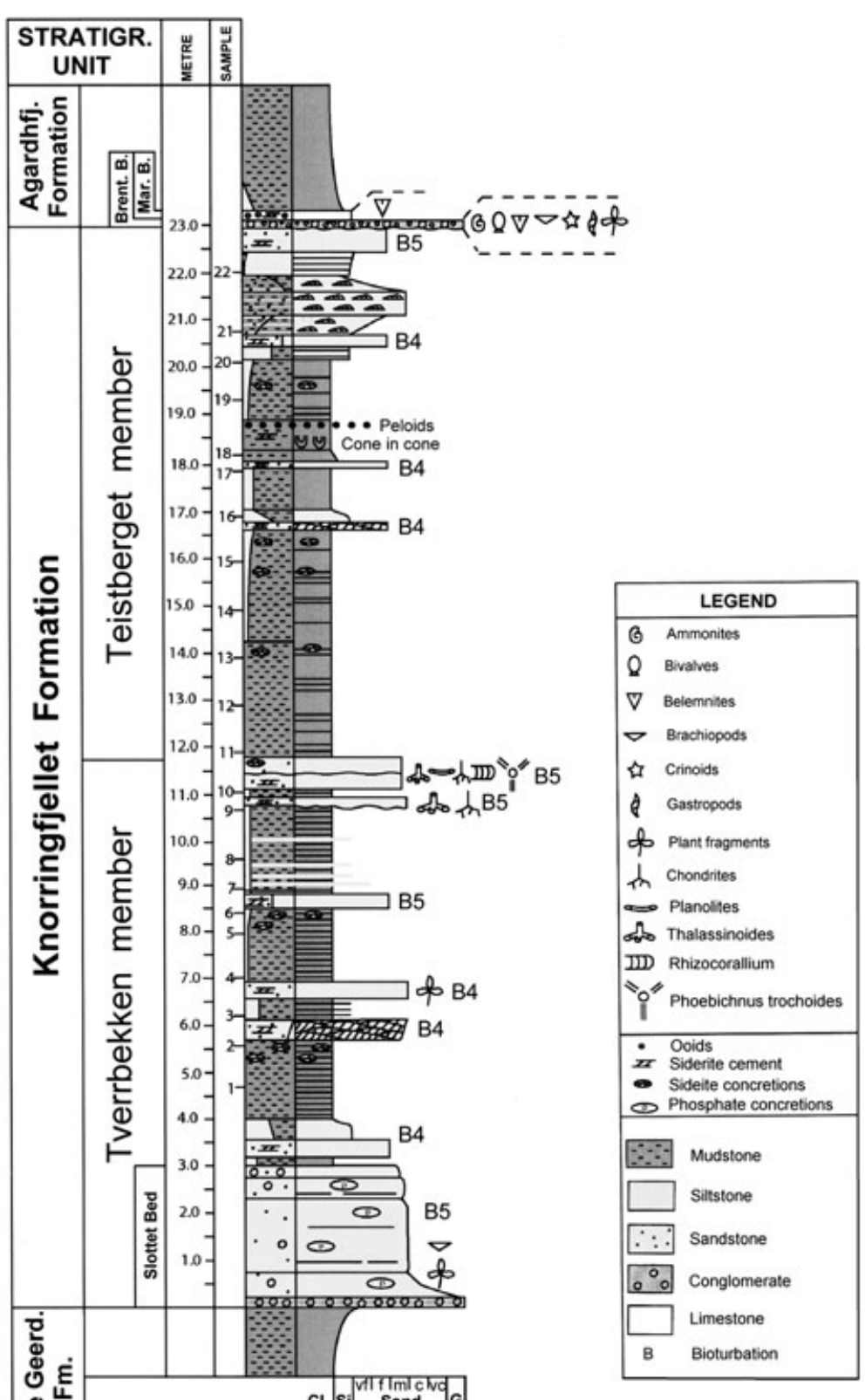

frequencies below $10 \%$. The $H(S)$ diversity ranges from 0.1 to 0.7 and shows an upward-decreasing trend; whereas the species dominance is correspondingly high, approaching $100 \%$ in the upper part of the member (Fig. 6).

The unconformity surface forming the upper boundary of the member is overlain by the Brentskardhaugen Bed, followed by the Marhøgda Bed. At this site both of these beds are thin and usually covered by beach gravel, but have been observed after removal of overburden. The clast content of the Bretskardhaugen Bed is strongly dominated by chert and quartzite, whereas phosphatic nodules occur sporadically. The overlying Marhøgda Bed is typified by its ooid content.

\section{Knorringfjellet Formation of the Marhøgda section}

The formation here is $17.2 \mathrm{~m}$ thick and consists mainly of mudstones with subordinate amounts of sandstones. The 


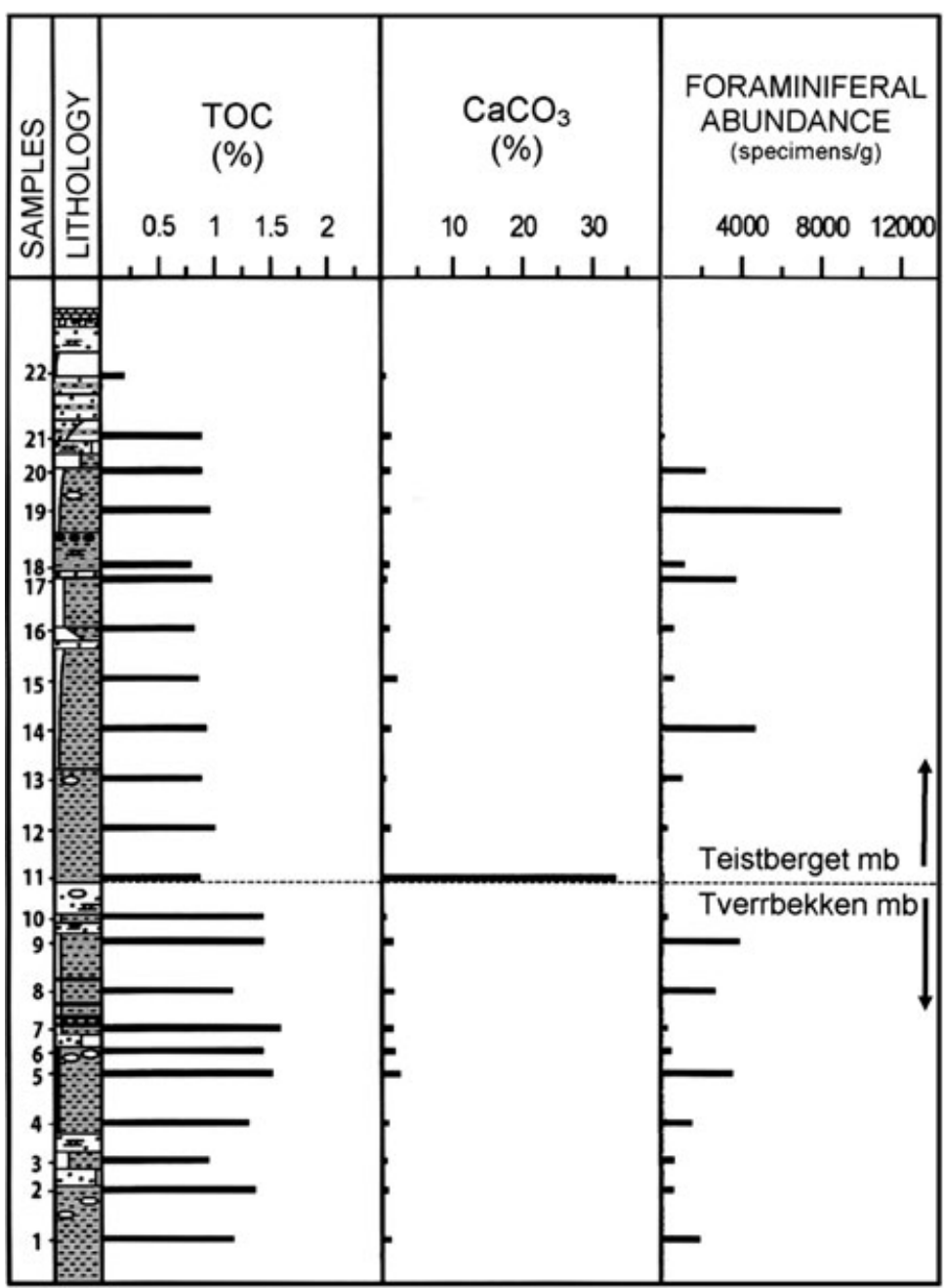

Fig. 4 Distribution of total organic carbon (TOC), calcium carbonate and foraminiferal abundance in the Knorringfellet Formation, Festningen section. mudstones vary from poorly laminated to non-laminated, and contain scattered siderite concretions. The TOC content of the mudstones ranges from 0.6 to $2.2 \%$ (average, $1.1 \%$ ), whereas their calcium carbonate content varies from 0.00 to $4.81 \%$ (average, $0.65 \%$ ).

The lower $12.2 \mathrm{~m}$ of the formation is composed of the Tverrbekken member (Fig. 7). Here also, the lower boundary of this member is defined by a conglomerate deposited at the transgressive base of the $2.5-\mathrm{m}$ thick sandstone, which comprises the bulk of the Slottet Bed. The clast content of the conglomerate is mainly quartzite, but scattered phosphatic pebbles are also present. The main mudstone body of the Tverrbekken member (above the Slottet Bed) contains five thin sandstone interbeds. The top surface of the uppermost sandstone is believed to represent the unconformity defining the boundary between the Tverrbekken and Teistberget members.

Mudstone is also the dominant lithology in the Teistberget member. The top of this member is defined by the regional unconformity, which is directly overlain by a well-developed Bretskardhaugen Bed with large phosphatic clasts, followed by a prominent Marhøgda Bed with its high ooid content.

In this section, the foraminiferal assemblages of the Knorringfjellet Formation are entirely agglutinated, are typified by small-sized taxa, and show low $H(S)$ diversities, ranging from 0.8 to 1.9 . The most abundant species through the section is $T$. aff. eoparva. Other quantitatively significant species include $A$. aff. yonsnabensis in the Tverrbekken member, and B. aff. vermiculus, Bulbobaculites oviloculus Nagy \& Seidenkrantz 2003 and Ammobaculites bivarians Nagy \& Seidenkrantz 2003 in the Teistberget member.

\section{Knorringfjellet Formation of the Juvdalen and Drønbreen sections}

In the Juvdalen section, the Knorringfjellet Formation is $23 \mathrm{~m}$ thick and consists of a lower sandstone-dominated interval and an upper mudstone-dominated one. Its 


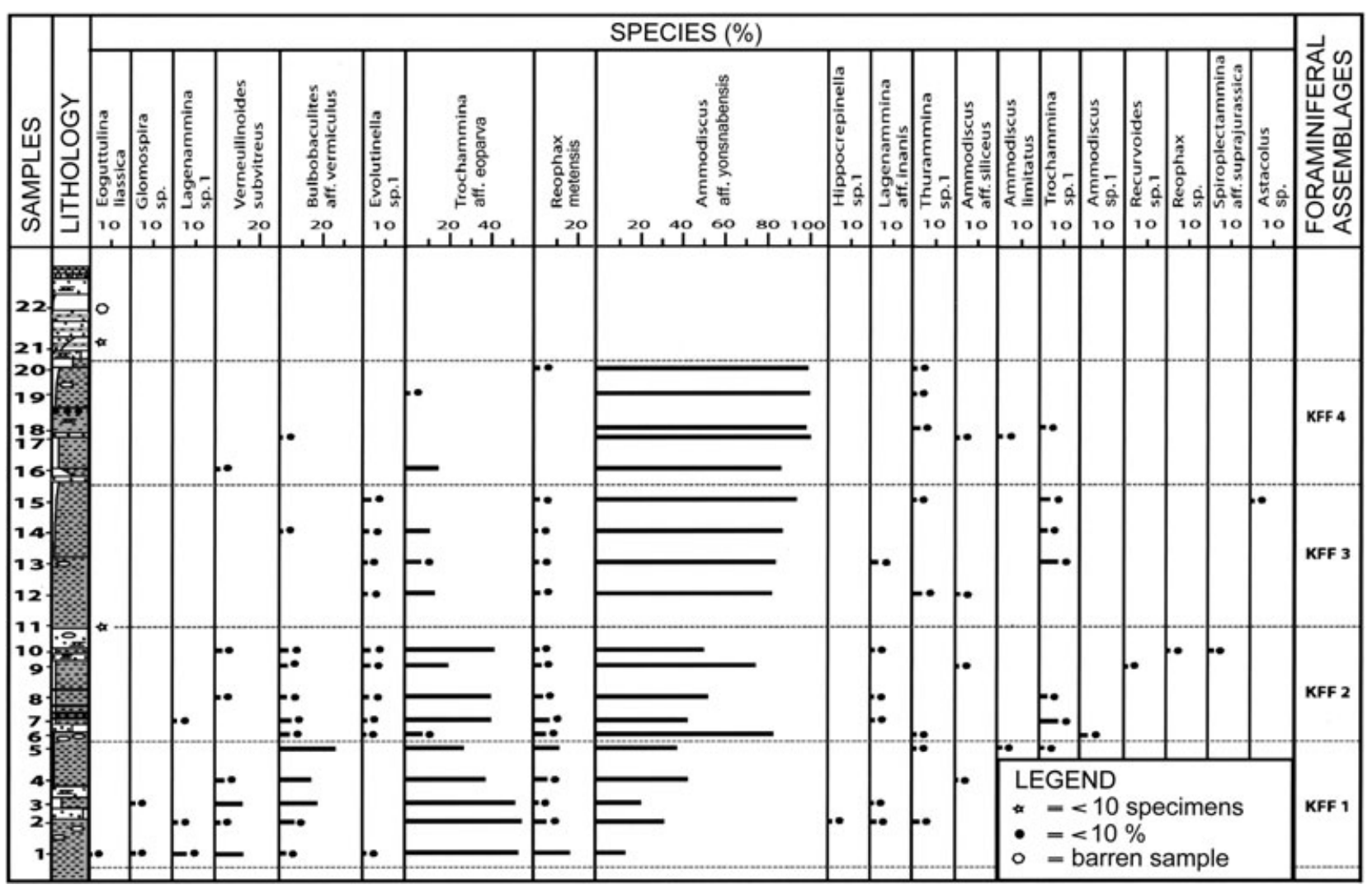

Fig. 5 Range chart of foraminiferal taxa in the Knorringfjellet Formation of the Festningen section, with subdivision into four assemblages. The contact between assemblage KFF 2 and KFF 3 represents the boundary between the Tverrbekken and Teistberget members.

foraminiferal assemblages consist of agglutinated taxa, are of extremely low diversity and are typified by smallsized forms. The most abundant species are $A$. aff. yonsnabensis and T. aff. eoparva.

In the Drønbreen section the thickness of the formation is reduced to $16 \mathrm{~m}$. Its lower part consists mainly of mudstones, whereas its upper part is strongly dominated by sandstones. Here also, the foraminiferal faunas consist of agglutinated taxa, the diversity is extremely low and the tests are generally of small size. The dominant species are A. aff. yonsnabensis, T. aff. eoparva and Evolutinella sp.

\section{Depositional conditions of the Knorringfjellet Formation}

\section{Environmental significance of the main faunal features}

As demonstrated, the foraminiferal assemblages of the Knorringfjellet Formation are entirely agglutinated, with the exception of a very few occurrences of calcareous taxa (Fig. 8). The species diversities are extremely low: the average $H(S)$ values are 1.2 in the Tverrbekken member of the Festningen section, 0.3 in the Teistberget member of the Festningen section, and 1.2 in the whole formation of the Marhøgda section. The alpha diversity values are correspondingly low, as shown by an average for the whole formation of 1.1 in the Festningen section and 1.8 in the Marhøgda section.

The alpha diversity index is commonly used when interpreting foraminiferal facies, because it allows comparison of samples of different assemblage size. Based on a wide range of data derived from modern environments, Murray (1973) demonstrated that alpha values of modern hyposaline waters are lower than 5. In addition, subsequent studies also revealed low alpha values of less than 5 in modern hypoxic environments.

The alpha indexes of individual samples from both the Festningen and Marhøgda sections are presented in a diversity diagram in Fig. 9. Although the values range between 0.5 and 4.7, they are concentrated between 1.0 and 2.0. These low values suggest restricted environmental conditions where salinity and the level of dissolved oxygen are the potential controlling factors, which will be further considered on the following pages. 


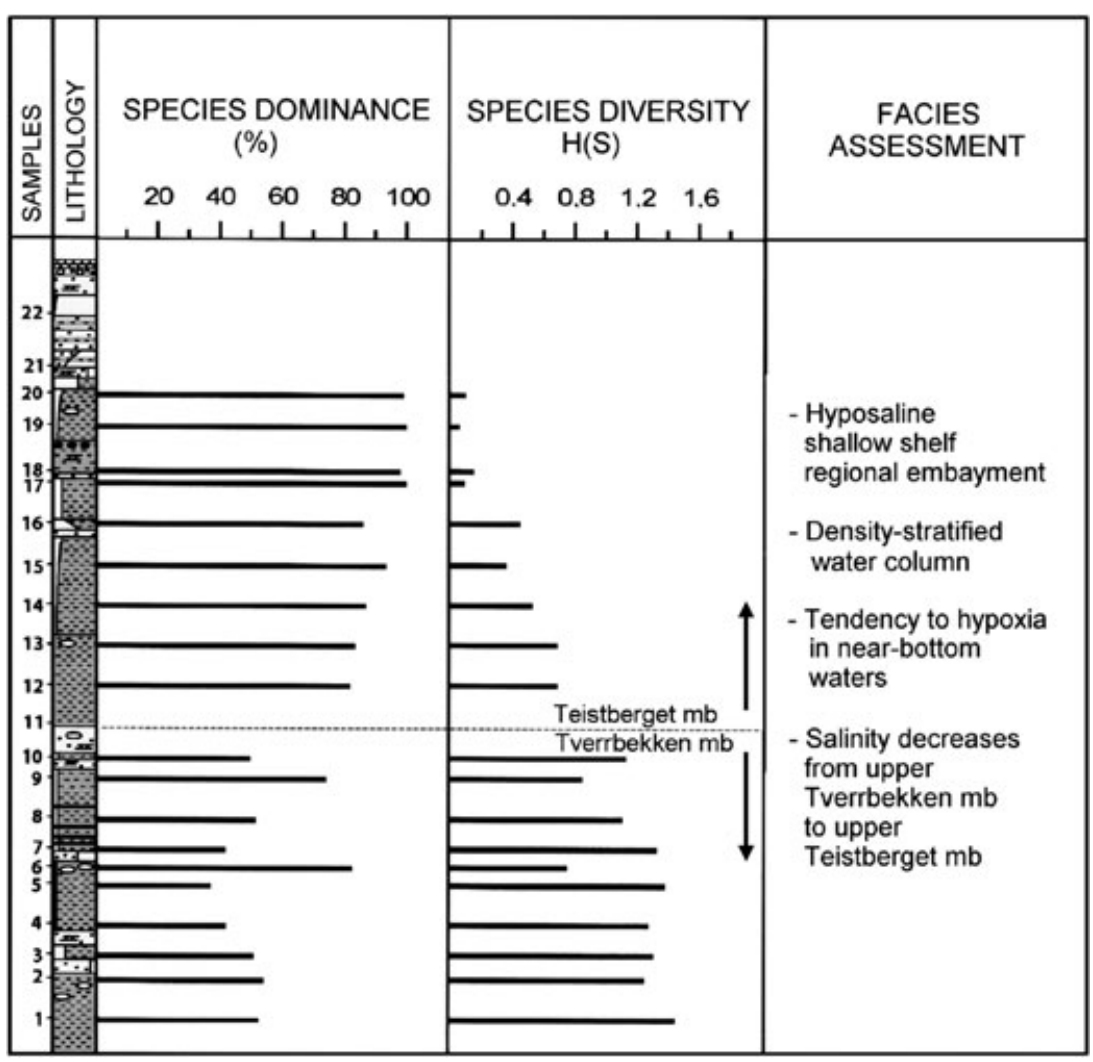

Fig. 6 Distribution of dominance and diversity characterizing foraminiferal assemblages in the Knorringfellet Formation at Festningen, including an assessment of foraminiferal facies.
High proportions of small-sized taxa in a foraminiferal assemblage appear to be another indicator of restricted environments. The two dominant species of the Knorringfjellet Formation, $A$. aff. yonsnabensis and $T$. aff. eoparva, are significantly smaller in size than is usual among Mesozoic representatives of Ammodiscus and Trohammina, respectively. In addition, several of the other genera are clearly of small dimensions compared with their sizes in other assemblages.

\section{A depositional facies model}

Hyposaline conditions during the deposition of the Knorringfjellet Formation are suggested by several features: no unequivocally normal marine salinity indicators (e.g., ammonites, belemnites and echinoderms) are observed in the formation at the Festningen section, and they are also absent from the three additional sections studied in central Spitsbergen. As demonstrated above, the foraminiferal assemblages are almost entirely agglutinated and of extremely low diversity. The two dominant foraminiferal genera in the formation, Ammodiscus and Trochammina, are abundant in some modern brackish waters, although they do also occur in other environments. The less common genus, Ammobaculites, is often associated with modern low-salinity estuarine conditions (Buzas 1974; Murray 1991).

The depositional area of the Knorringfjellet Formation was a relatively shallow sea, but of variable depth. The presence of hiatuses indicates erosion or sediment bypass, whereas the occurrence of sandstone interbeds suggests periods of shoreface water depths. The mudstone intervals appear homogeneous, and were deposited below the fair-weather wave base, or even below the storm wave base.

Hyposaline conditions imply a gravity-stratified water column. This has a tendency to create hypoxic conditions in the lower water layers, up to the storm wave base or even up to the normal wave base. It seems probable that such stagnant conditions developed seasonally, or more permanently during deposition of the mudstones forming the bulk of the Knorringfjellet Formation. This assessment is supported by the fact that some modern morphological analogues of the most dominant taxa of the Knorringfjellet Formation are abundant in modern salinity-stratified environments with hypoxic bottom water (discussed below).

The palaeogeography of the western Barents Sea region, including Svalbard, in Carnian (De Geerdalen Formation) time is envisaged by Nøttvedt et al. (1992). 
Fig. 7 Diagrams comparing distribution of the information function $H(S)$ diversity and frequency of the most abundant taxa in the Festningen and Marhøgda sections.

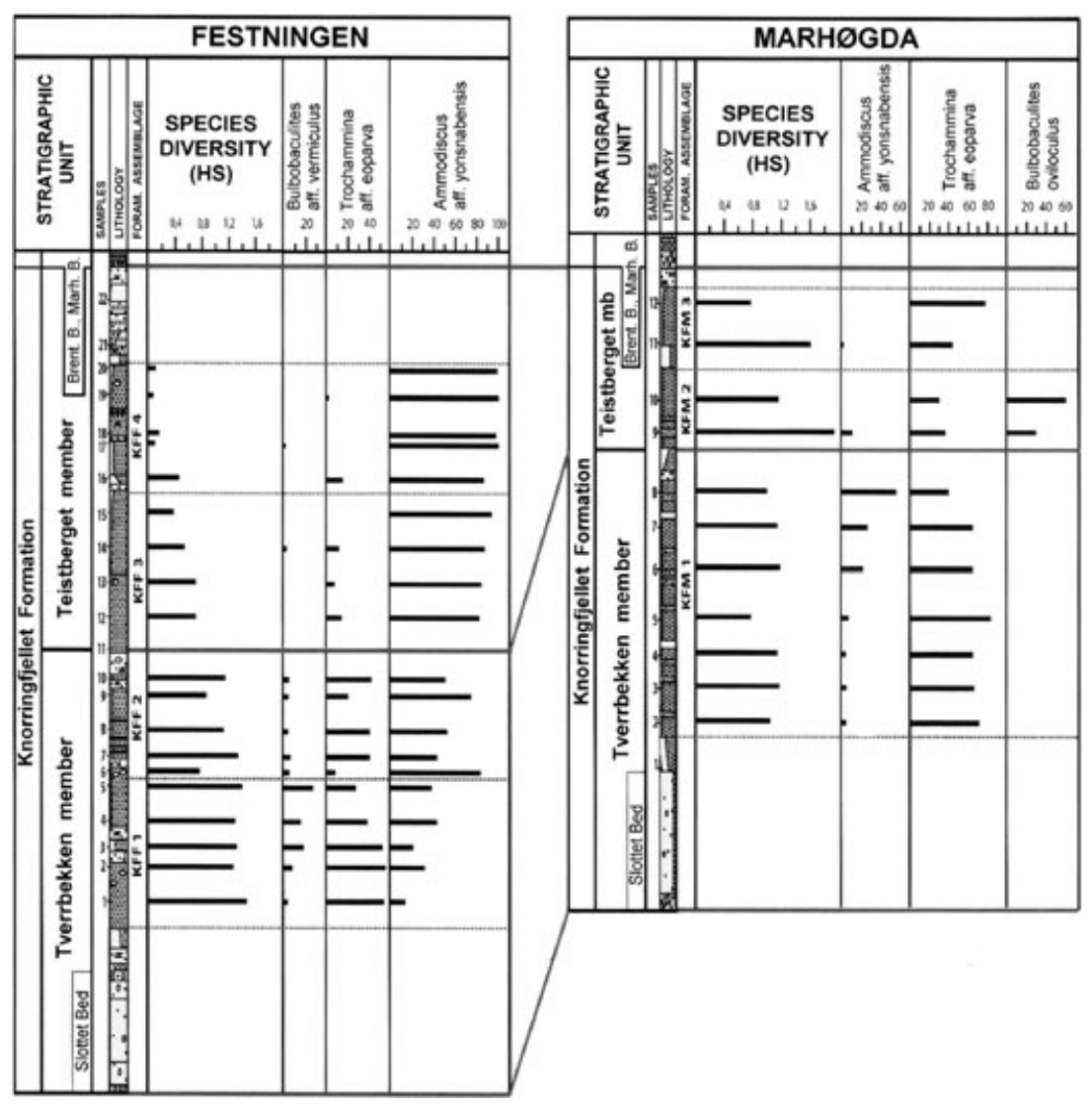

According to this reconstruction, the region was covered by a large north-south elongated shelf sea embayment. Fresh water run-off from extensive southern, eastern and western land areas discharged to this seaway. Van Veen et al. (1992) proposed that a large deltaic system built out from the south-western Barents Sea into this shelf embayment. We consider that this embayment was closed towards the south, between northern Norway (Troms) and Greenland, but had an open communication northwards with the polar basin across the Svalbard Archipelago.

Development of brackish conditions on the Knorringfjellet shelf would be explained by the considerable fluvial discharge. The freshwater input created a densitystratified water column with a tendency to hypoxia at depths below the fair-water wave base or the storm wave base, which are the sites of mud deposition. Modern shallow water continental shelf hypoxia is exemplified by the inner and middle shelf of the northern Gulf of Mexico, off the Louisiana coast, summarized by Rabalais et al. (1991). Hypoxic near-bottom waters are formed seasonally there during midsummer, and may cover up to $9500 \mathrm{~km}^{2}$ at a water depth of 5-60 m. Development of the stratified water column is mainly controlled by the Mississippi and Atchafalaya rivers, regional wind fields and the current system.

The extremely low calcium carbonate content that characterizes the Knorringfjellet Formation (Fig. 4) is in accordance with deposition in hyposaline waters. The average carbonate content of the Festningen section is $0.76 \%$ in the Tverrbekken member, and is $0.61 \%$ in the Teistberget member (except for the high value at the main unconformity level). Similarly low values were also measured in the Marhøgda section. These low carbonate values do not seem to be a post-depositional diagenetic feature of these deposits. Their non-decalcified nature is indicated by the absence of pyrite internal moulds of calcareous foraminifera and by the presence of calcareous tests, although in very low number.

In the Festningen section the TOC content of the Tverrbekken member (average, 1.3\%) is higher than in the Teistberget member (average, $0.8 \%$ ). This suggests that the oxygen depletion was more severe during deposition of the Tverrbekken member than during deposition of the Teistberget member (Fig. 4). In the middle and upper part of the Knorringfjellet Formation in this 


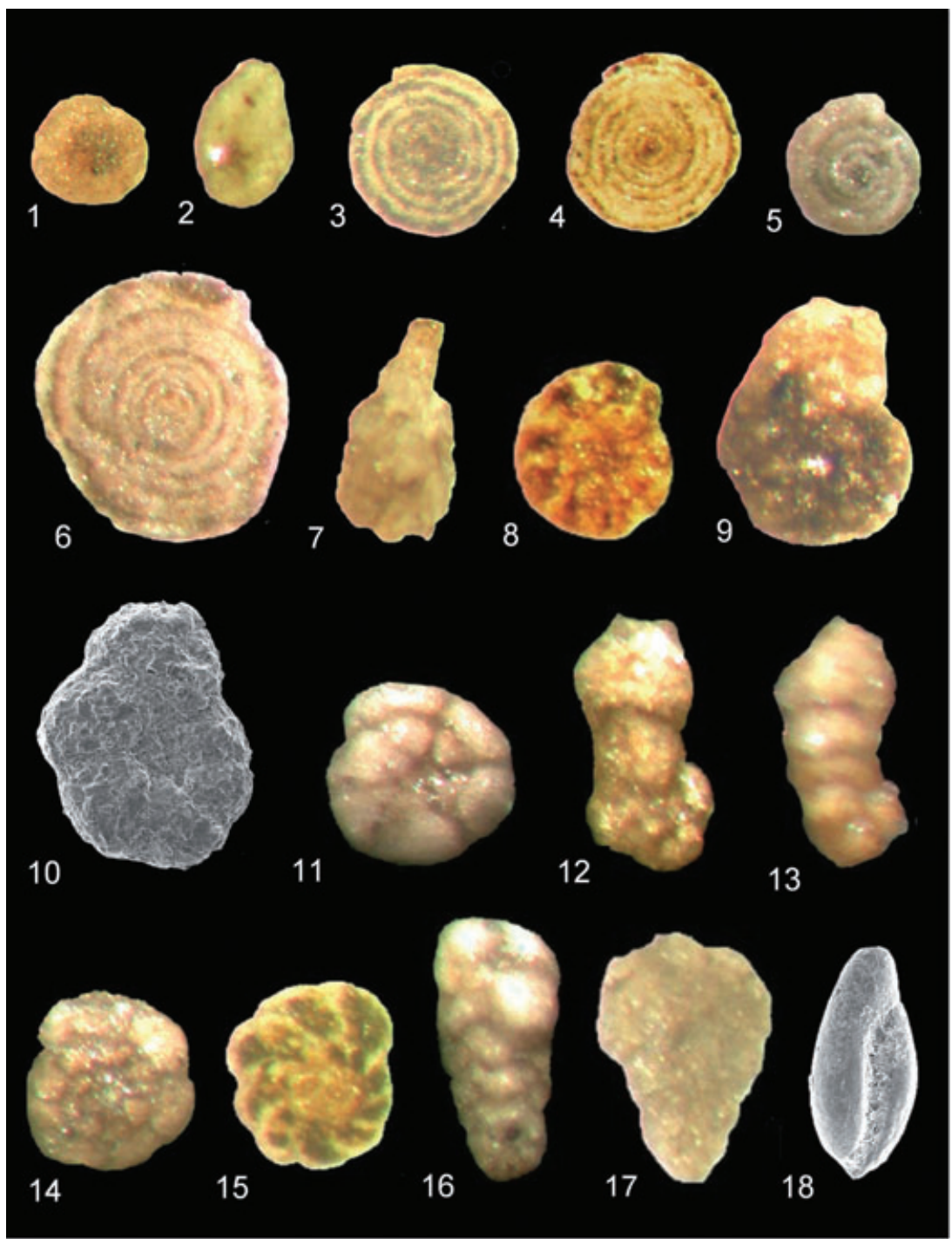

Fig. 8 The most common and some other characteristic foraminiferal species of the Knorringfjellet Formation. All images are reflectedlight photographs, except nos. 10 and 18, which are scanning electron micrographs. (1) Thurammina sp. 1, Marhøgda section, sample 9, X115; (2) Lagenammina aff. inanis, Festningen section, sample 2, X150; (3-4) Ammodiscus aff. yonsnabensis, Festningen section, sample 17, X130; (5) Ammodiscus sp. 1, Festningen section, sample 6, X150; (6) Ammodiscus aff. siliceous, Festningen section, sample 17, X150; (7) Reophax metensis, Marhøgda section, sample 2, X120; (8) Evolutinella sp. 1, Festningen section, sample 8, X265; (9) Kutsevella sp. 1, Marhøgda section, sample 11, X130; (10) Kutsevella aff. haplophragmoides, Marhøgda section, sample 9, X110; (11) Recurvoides sp. 1, Marhøgda section, sample 7, X185; (12) Bulbobaculites oviloculus, Marhøgda section, sample 9, X205; (13) Bulbobaculites aff. vermiculus, Marhøgda section, sample 6, X185; (14) Trochammina aff. eoparva, Marhøgda section, sample 7, X205; (15) Trochammina sp. 1, Festningen section, sample 7 , X200; (16) Verneuilinoides subvitreus, Marhøgda section, sample 4, X195; (17) Verneuilinoides aff. kirillae, Marhøgda section, sample 10, X125; (18) Eoguttulina liassic, Festningen section, sample $1, \mathrm{X} 135$. section, the faunal diversity decreases upwards, whereas the percentage of $A$. aff. yonsnabensis increases in the same direction (Figs. 6, 7). These developments might be explained by upward decreasing salinity associated with increasing oxygenation, which are further supported by the increased silt content and blocky weathering of the Teistberget mudstones, suggesting slightly decreased water depth and the presence of diffuse bioturbation, respectively.

In the Marhøgda section the TOC content is on average $1.1 \%$, and the average calcium carbonate is $0.65 \%$. Thus, both parameters have essentially similar values to those of the Festningen section. The Teistberget member in the Marhøgda section, however, shows significantly higher diversities, a higher content of $T$. aff. eoparva and a much lower content of $A$. aff. yonsnabensis than the same member in the Festningen section (Fig. 7). These features suggest that during deposition of the Teistberget member there was an increased hyposaline influence in the Festningen area.

\section{Comparisons with analogue assemblages and environments}

\section{Ancient analogues}

Low-diversity agglutinated assemblages have been interpreted in several papers during the last decades as having developed under restricted environmental conditions: e.g., Early and Middle Jurassic faunas of the North Sea Basin attributed to hyposaline or hypoxic conditions, including prodelta, delta plain and hypoxic shelf settings (Nagy et al. 1990); Middle Jurassic assemblages of the Inner Moray Firth Basin ascribed to hypoxic conditions 


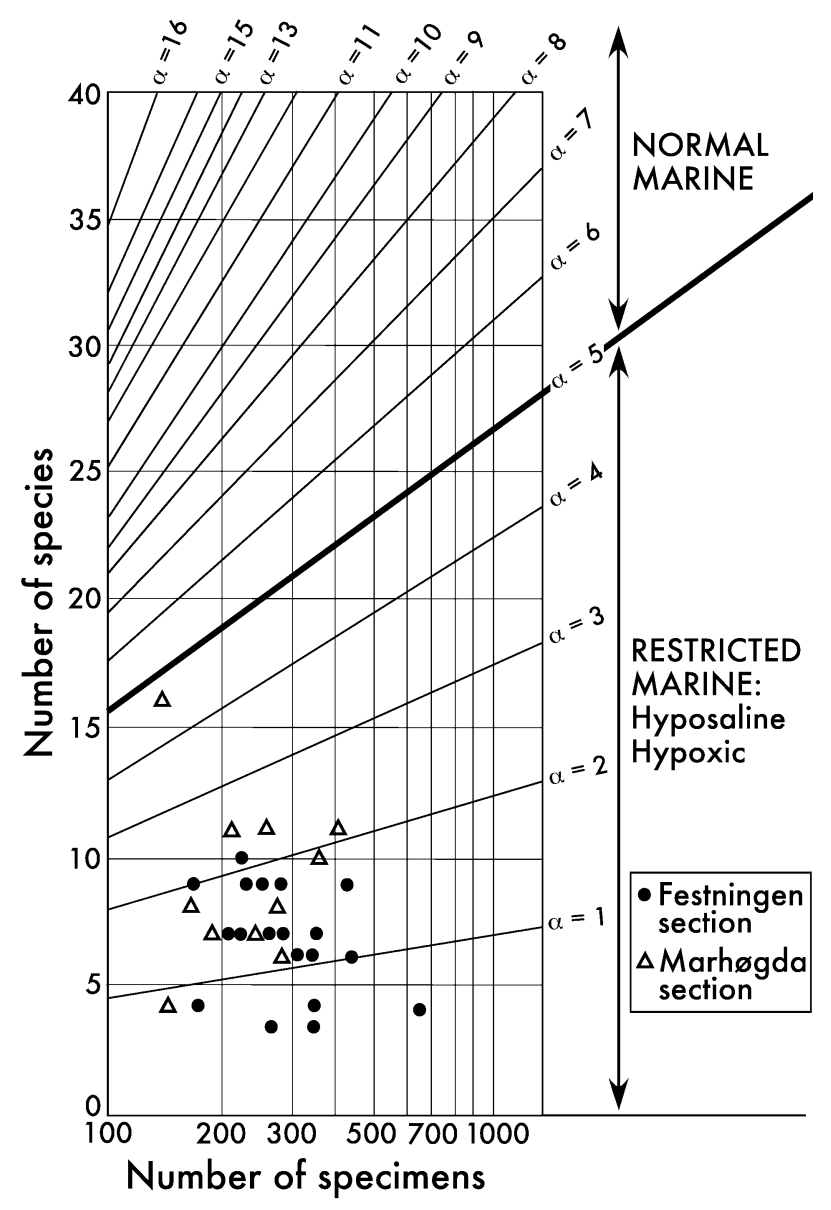

Fig. 9 Alpha diversity plot of foraminiferal samples from the Knorringfellet Formation of the Festningen $(\mathbf{O})$ and Marhøgda $(\triangle)$ sections. Samples from modern restricted environments generally lie below alpha $=5$.

(Nagy et al. 2001); Early Jurassic faunas of the Danish Basin referred to a hyposaline prodelta setting (Nagy \& Seidenkrantz 2003). All of these environmental assessments are primarily based on a combination of biofacies and sedimentary facies data.

A Middle Jurassic analogue for the Knorringfjellet assemblages is found in the Aalenian lower part of the Rannoch Formation sampled in the Gullfaks Oil Field of the northern North Sea, and recorded by Nagy $\&$ Johansen (1991). The Rannoch assemblages are entirely agglutinated and show extremely low diversities, with an average alpha index value of 1.1 (Fig. 10). The dominant species are A. yonsnabensis (18-100\%), and T. eoparva (3-65\%), both with a typically small test size. The lower Rannoch deposits containing these assemblages are referred to a deltaic embayment, with low salinity as the main factor controlling the development of foraminiferal assemblages. An additional restricting factor might have been weak oxygen depletion in the benthic environment, although the TOC content of the sediment is on average only $1.7 \%$. This relatively low value might be explained by a high influx of clay diluting the organic component.

Another Middle Jurassic analogue to the Knorringfjellet assemblages occurs in the Bajocian Yons Nab Beds of the Yorkshire coast, described by Nagy et al. (1983). The lower and upper parts of the Yons Nab Beds are heavily dominated by the small-sized A. yonsnabensis, composing $58-100 \%$ of the fauna (Fig. 10). The middle parts of the Yons Nab section are dominated by calcareous taxa, mainly Spirillinids. Here also, the species diversity is extremely low, with an average alpha of 0.9 . The depositional environment of the Yons Nab succession is assessed to have been a shallow water hyposaline interdistributary bay, formed during a marine transgression inundating the Middle Jurassic delta plain.

\section{Modern analogues}

Comparison of Mesozoic foraminiferal assemblages with modern faunas, with regard to major faunal features such as shell-type groups, diversities and related parameters, is an important approach to Mesozoic facies interpretation. It is reasonable to assume that species diversity is primarily controlled by the number of niches available to foraminifera in a given environmental setting. We can expect that the number of niches in a certain environment has not changed significantly during Mesozoic and Cenozoic times. This warrants the application of modern diversity data (e.g., the alpha index) and similar information to the interpretation of ancient assemblages.

Comparisons with modern faunas using lower taxonomic units are complicated, owing to the extensive phylogenetic changes that have taken place during foraminiferal evolution in late Cretaceous and Cenozoic times. Several calcareous taxa of the Superfamily Rotaliacea that evolved during the Cenozoic are dominant in many modern hyposaline environments. A similar extensive radiation is evident in the Superfamiles Bolivinacea and Turrilinacea, members of which are typical in many modern hypoxic environments. It seems highly probably that the dominant calcareous group during the Mesozoic, the Suborder Lagenina, was essentially a normal marine group not adapted to restricted environmental conditions (Nagy et al. 1990). Consequently, modern faunas taxonomically analogous to Mesozoic assemblages are not commonly found, although two examples are presented below.

Ammodiscus gullmarensis Höglund 1948, found today in the Drammensfjord in southern Norway, is an analogue for $A$. aff. yonsnabensis of the Knorringfjellet Formation, both in its small size and in its general appearance (Fig. 11). Drammensfjord possesses an 


Yorkshire coast
Bajocian, Cloughton Formation, Yons Nab Beds
Dominant species: Ammodiscus yonsnabensis
Frequency: $58-100 \%$, average $76 \%$
Alpha diversity: average 0.9
TOC: average 0.8
Environmental assessment: shallow water
hyposaline interdistributary bay
Northern North Sea, Gullfaks Field
Aalenian, Rannoch Formation lower part
Dominant species: Ammodiscus yonsnabensis
Abundant species: Trochammina eoparva
Frequency: $3.0-65 \%$, average $25 \%$
Alpha diversity: average 1.1
TOC: average $1.7 \%$
Environmental assessment: hyposaline deltaic
embayment, tendency to bottom water hypoxia

\section{A. gullmarensis}

Modern, south-east Norway

Dominant species: Ammodiscus gullmarensis Frequency: 21-58 \%, average $37 \%$

Alpha diversity: 1.9-3.9, average 0.9

Water depth: 15-38 m

Salinity: 24-30 \%

Oxygen: $1.7-4.4 \mathrm{ml} / \mathrm{l}$

TOC: average 0.8

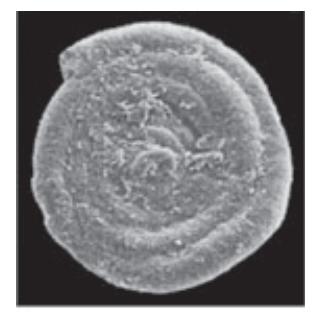

Aso-kai Lagoon

Modern, central Japan

Dominant species: Trochammina cf. japonica

Frequency: 1.0-54 \%, average $18 \%$

Alpha diversity: 0.9-2.4, average 1.5

Water depth: 13.3-12.3 m

Salinity: 28-30\%

Oxygen: $1.4-12.4 \mathrm{ml} / \mathrm{l}$

TOC: $0.1-5.8$, average 0.8

\section{T. cf. japonica}

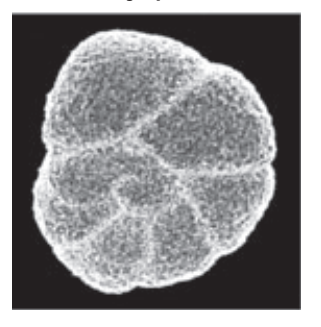

Fig. 10 Environments of Jurassic morphological analogues of the two most abundant foraminiferal species occurring in the Knorringfjellet Formation.
Fig. 11 Environments of modern morphological analogues of the two most dominant foraminiferal species occurring in the Knorringfjellet Formation. estuarine stratification, with a strongly hyposaline upper water layer created by high fluvial discharge. With increasing water depth the salinity increases, whereas the oxygen content decreases. According to Alve (1995), the A. aff. gullmarensis fauna is developed at a water depth of 15-38 m, where the nominate species occurs with a frequency of $21-58 \%$. This is a mixed fauna of agglutinated and calcareous taxa, but shows a low alpha diversity ranging from 1.9 to 3.9. Through this depth interval the salinity increases downwards from 24 to 
$30 \%$, whereas the oxygen concentration decreases from 4.4 to $1.7 \mathrm{ml} \mathrm{l}^{-1}$.

A modern analogue to T. aff. eoparva of the Knorringfjellet Formation is Trochammina cf. japonica Ishiwada 1950, which is a dominant species in the brackish coastal waters of Japan (Fig. 11). Some of these latter environments, such as the shallow Aso-kai Lagoon, develop hypoxic conditions in the lower part of the water column during the summer season. The foraminiferal fauna of this site was recorded by Takata et al. (2005). They found that $T$. cf. japonica occurs at water depths of 3.3-12.3 m, where this species accounts for $1.0-54 \%$ of the fauna, which is a mixture of agglutinated and calcareous taxa, and its alpha diversity value varies from 0.9 to 2.4. The salinity increases with increasing depth from 28 to $30 \%$ o through this interval of the water column, whereas the oxygen content decreases markedly from 12.4 to $1.4 \mathrm{ml} \mathrm{l}^{-1}$.

\section{Stratigraphic discontinuities in the Knorringfjellet Formation}

To detect stratigraphic unconformities and associated hiatus surfaces, the degree of similarity in faunal composition between adjacent samples in the stratigraphic succession has been measured by means of the Sanders similarity index. The results from the Festningen section are presented in Fig. 12. There are two closely-spaced major discontinuities in the Tverrbekken member, located between samples 5, 6 and 7, whereas a larger faunal break is also present at the contact between the Tverrbekken and Teistberget members. At these three levels the similarity is below $70 \%$. In addition, two minor discontinuities occur in the upper parts of both members.

In general, the sizes of the observed discontinuities appear moderate to small, taking into consideration the large time span, the limited thickness and the generally accepted content of large hiatuses of the formation. The discrepancy between observed and anticipated discontinuity values are ascribed to the temporal stability of restricted (mainly hyposaline) environments. In the depositional area of the Knorringfjellet Formation, such conditions lasted essentially unchanged from the Norian to the Bajocian, and apparently obscured even major hiatuses.

\section{Conclusions}

The Knorringfjellet Formation in western and central Spitsbergen consists of mudstones and sandstones deposited at offshore and shoreface water depths, respectively. The long stratigraphic time span (Norian-Toarcian) and limited thickness of the formation (16-26 $\mathrm{m}$ in the

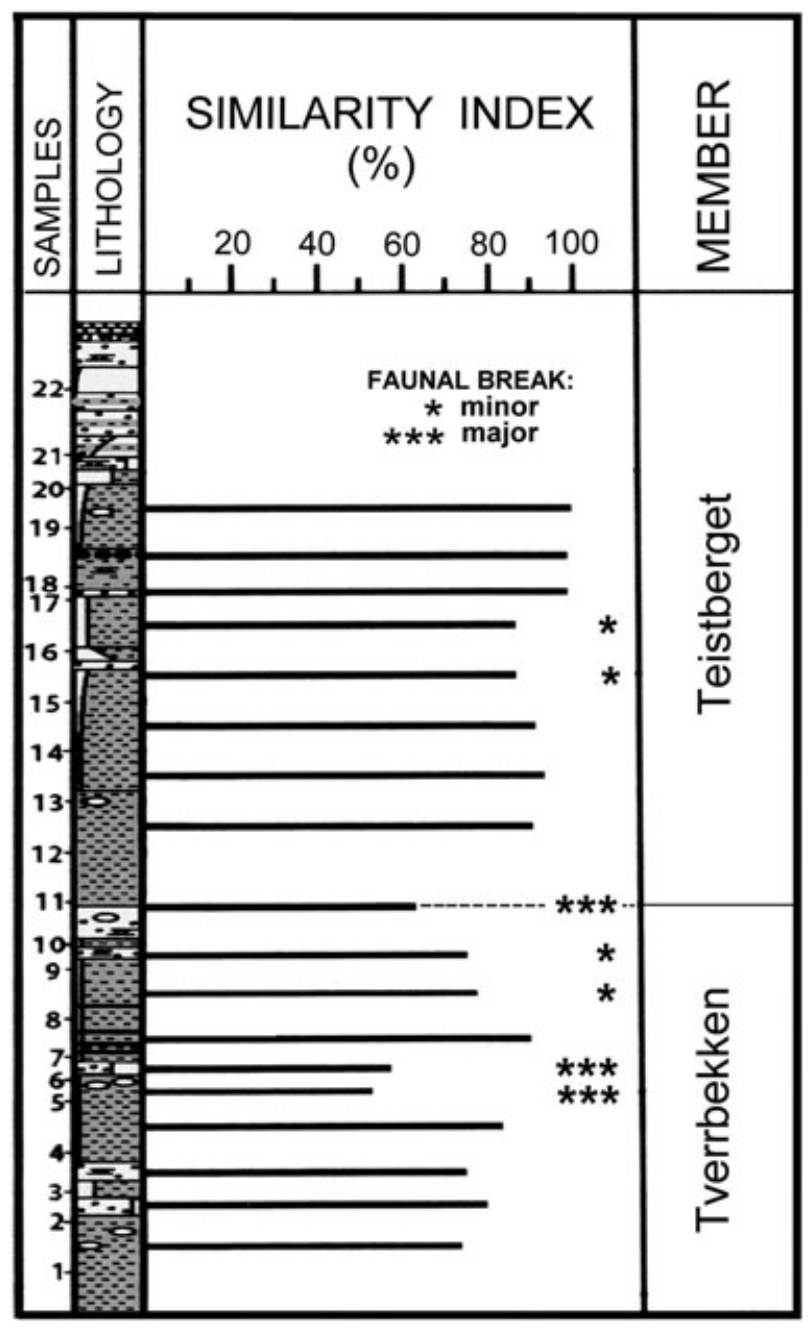

Fig. 12 Foraminiferal similarity index through the Knorringfjellet Forma tion at Festningen. Low similarity values between adjacent samples suggest faunal breaks associated with unconformities.

studied sections) is in accordance with its partially condensed nature and content of major unconformities.

The foraminiferal assemblages of the formation are virtually agglutinated, are of extremely low diversity and are dominated by species significantly smaller in size than related taxa in apparently normal marine environments. These features are regarded to indicate restricted (stressed) environmental conditions. The dominant species are $A$. aff. yonsnabensis and T. aff. eoparva.

Comparisons with ancient and modern faunal analogues suggest that the main restricting factor was the hyposaline nature of the water masses. The essentially salinity-controlled stratification of the water column had a tendency to create hypoxia, which acted as an additional restricting factor in near-bottom waters. 
The extremely low calcium carbonate content of the Knorringfjellet mudstones, together with the absence of normal marine salinity indicators, is in accordance with hyposaline conditions. The TOC content of the mudstones is significantly lower than for typically hypoxic (organic-rich) mudstones. The relatively low measured values are ascribed to the dilution of organic matter by high minerogenic supply during sedimentation.

The depositional area of the Knorringfjellet Formation was an extensive north-south elongated shelf embayment, which was closed towards the south but had an open communication northward with the polar oceanic basin. Delta developments on the margins of this seaway imply a high fluvial discharge, causing salinity stratification of the water column.

The foraminiferal succession reveals faunal discontinuities at several levels within the formation, recognized by means of a similarity index. The discontinuities are interpreted to indicate hiatuses coupled with unconformities. The magnitude of the discontinuities (as expressed by the fauna) is relatively moderate, owing to the stability of restricted environmental conditions during stratigraphic time.

\section{Acknowledgements}

The project was supported by the Statoil-VISTA programme, which covered general research expenses. We greatly appreciate the enthusiastic assistance provided during the fieldwork by students of the University Centre in Svalbard. Thanks are also extended to Jon Reierstad, University of Oslo, for drafting some of the illustrations.

\section{References}

Alve A. 1995. Benthic foraminiferal distribution and recolonization of formerly anoxic environments in Drammensfjord, southern Norway. Marine Micropaleontology 25, 169-186.

Bäckström S.A. \& Nagy J. 1985. Depositional history and fauna of a Jurassic phosphorite conglomerate (the Brentskardhaugen Bed) on Spitsbergen. Norsk Polarinstitutt Skrifter 183. Oslo: Norwegian Polar Institute.

Bjærke T. \& Dypvik H. 1977. Sedimentological and palynological studies of Upper Triassic-Lower Jurassic sediments in Sassenfjorden, Spitsbergen. Norsk Polarinstitutt Årbok 1976, 131-150.

Buzas M.A. 1974. Vertical distribution of Ammobaculites in the Rhode River, Maryland. Journal of Foraminiferal Research 4, 144-177.

Korčinskaja M.V. 1980. Rannenoriskaja fauna Arhipelaga Svalbard. (Early Norian fauna of the Svalbard Archipelago.) In D.V. Semevskij (ed.): Geologija osadočnogo čehla arhipelaga Sval'bard. (Geology of the sedimentary cover of
Svalbard.) Pp. 30-43. Leningrad: Institute of Arctic Geology.

Mørk A., Dallmann W.K., Dypvik H., Johannessen P., Larssen G.B., Nagy J., Nøttvedt A., Olaussen S., Pčelina T.M. \& Worsley D. 1999. Mesozoic lithostratigraphy. In W.K. Dallmann (ed.): Lithostratigraphic lexicon of Svalbard. Upper Palaeozoic to Quaternary bedrock. Review and recommendations for nomenclature use. Pp. 127-214. Tromsø: Norwegian Polar Institute.

Mørk A., Knarud R. \& Worsley D. 1982. Depositional and diagenetic environments of the Triassic and Lower Jurassic of Svalbard. In A.F. Embry \& H.R. Balkwill (eds.): Arctic geology and geophysics: proceedings of the Third International Symposium on Arctic Geology. Pp. 371-398. Calgary: Canadian Society of Petroleum Geologists.

Murray J.W. 1973. Distribution and ecology of living benthic foraminiferids. London: Heinemann Education Books.

Murray J.W. 1991. Ecology and palaeoecology of benthic foraminifera. London: Longman Scientific and Technical.

Murray J.W. 2006. Ecology and applications of benthic foraminifera. New York: Cambridge University Press.

Nagy J. 2005. Delta-influenced foraminiferal facies and sequence stratigraphy of Paleocene deposits in Spitsbergen. Palaeogeography, Palaeoclimatology, Palaeoecology 222, 161-179.

Nagy J., Finstad E., Dypvik H. \& Bremer M.G.A. 2001. Response of foraminiferal facies to transgressive-regressive cycles in the Callovian of northeast Scotland. Journal of Foraminiferal Research 34, 324-349.

Nagy J. \& Johansen H.O. 1991. Delta-influenced foraminiferal assemblages from the Jurassic (Toarcian-Bajocian) of the northern North Sea. Micropaleontology 37, 1-40.

Nagy J., Løfaldli M. \& Bomstad K. 1983. Marginal marine microfaunas of the Jurassic (Bajocian) Yons Nab Beds of the Yorkshire Coast. In J.G. Verdenius et al. (eds.): Proceedings of the First Workshop on Arenaceous Foraminifera, 7-9 September 1981, Amsterdam. Pp. 111-127. Trondheim: Continental Shelf Institute.

Nagy J., Pilskog B. \& Wilhelmsen R. 1990. Facies controlled distribution of foraminifera in the Jurassic North Sea Basin. In C. Hemleben et al. (eds.): Paleoecology, biostratigraphy, paleoceanography and taxonomy of agglutinated foraminifera. Pp. 621-657. Dordrecht: Kluwer Academic Press.

Nagy J. \& Seidenkrantz M.-S. 2003. New foraminiferal taxa and revised biostratigraphy of Jurassic marginal marine deposits on Anholt, Denmark. Micropaleontology 49, 27-46.

Nøttvedt A., Cecchi M., Gjelberg G.J., Kristensen S.E., Lønøy A., Rasmussen A., Rasmussen E., Skott P. H. \& van Veen P.M. 1992. Svalbard-Barents Sea correlation: a short review. In T.O. Vorren et al. (eds.): Arctic geology and petroleum potential: proceedings of the Norwegian Petroleum Society Conference, Tromsø, Norway, 15-17 August 1990. Pp. 363-375. Amsterdam: Elsevier.

Pčelina T.M. 1965. Mezozojskie otloženija rajona Van-Kejlenfjorda Zapadnyj Špicbergen. (Mesozoic deposits 
around Van Keulenfjorden, western Spitsbergen.) In V.N. Sokolov (ed.): Materialy po geologii Špicbergena. (Data on the geology of Spitsbergen.) Pp. 149-173. Leningrad: Institute of Arctic Geology.

Pčelina T.M. 1980. Novye dannye po pograničym slojam trias i jury na arhipelage Sval'bard. (New data on the Triassic-Jurassic boundary beds in the Svalbard Archipelago). In D.V. Semevskij (ed.): Geologija osadočnogo čehla arhipelage Sval'bard. (Geology of the sedimentary cover of Svalbard.) Pp. 4-60. Leningrad: Institute of Arctic Geology. (In Russian with English abstract on p. 136.)

Pemberton R.W. \& MacEachern J.A. 1992. Trace fossil facies models: environmental and allostratigraphic significance. In R.G. Walker \& N.P. James (eds.): Facies models. 3rd edn. Pp. 47-72. St. Johns, NL: Geological Association of Canada.

Rabalais N.N., Turner R.E., Wiseman W.J. Jr. \& Boesch D.F. 1991. A brief summary of hypoxia on the northern Gulf of
Mexico continental shelf: 1985-1988. In R.V. Tyson \& T.H. Pearson (eds.): Modern and ancient continental shelf anoxia. Geological Society Special Publication 58. Pp. 35-47. London: The Geological Society.

Sanders H.L. 1960. Benthic studies in the Buzzards Bay III. The structure of the soft bottom community. Limnology Oceanography 5, 138-153.

Takata H., Seto K., Sakai S., Tanaka S. \& Takayasu K. 2005. Correlation of Virgulinella fragilis Grindell \& Collen (benthic foraminiferid) with near-anoxia in Aso-kai Lagoon, central Japan. Journal of Micropaleontology 24, 159-167.

van Veen P.M., Skjold L.J., Kristensen S.E., Rasmussen A., Gjelberg J. \& Stølen T. 1992. Triassic sequence stratigraphy in the Barents Sea. In T.O. Vorren et al. (eds.): Arctic geology and petroleum potential: proceedings of the Norwegian Petroleum Society Conference, 15-17 August 1990, Tromsø, Norway. Pp. 515-538. Amsterdam: Elsevier. 